\title{
Women Board of Directors and Financial Performance: Mining Sector Companies Listed in Indonesia Stock Exchange
}

\author{
Yani Zulvina $^{1^{*}} \quad$ Makhdalena $^{2} \quad$ Desi Zulvina $^{3} \quad$ Fitri Zulvina $^{4}$ \\ 1.Faculty of Economics and Business, Riau University , 28124, Pekanbaru, Indonesia \\ 2.Faculty of Teacher Training and Education, Riau University, 28124, Pekanbaru, Indonesia \\ 3.Faculty of Economics and Business, Sebelas Maret University, 57126, Solo, Indonesia \\ 4.Directorate General of Taxes, 13140, Jakarta, Indonesia
}

\begin{abstract}
This study aimed to examine the existence of female directors and their impact on the company's financial performance of Mining sector companies listed on Indonesian Stock Exchange which had information about Female Directors, ROA and control variables such as size, leverage and age during 2017-2019. The type of data from this research was secondary data. Data source for women directors was obtained from idx.co.id and data on ROA, size, leverage and age was obtained from Thomson \& Reuters. The data analysis technique in this study used path analysis with SPSS. The results showed that the presence of female directors had no effect on the performance of the mining sector financial companies listed on the IDX as well as the control variables except size.
\end{abstract}

Keywords: Agency Problem, Female Directors, Financial Performance

DOI: $10.7176 / \mathrm{RJFA} / 12-10-11$

Publication date:May $31^{\text {st }} 2021$

\section{Introduction}

The purpose of establishing a company is to improve the welfare of stakeholders. Stakeholder welfare can increase if the company can improve its financial performance. According to Adam Smith (1776) financial performance can be improved if there is specialization. So there must be a separation between the owner (principal) and the manager (agent). Managers (agents) are individuals who according to agency theory (Jensen and Meckling, 1976) are self-interested who always want to improve their welfare even though they must sacrifice the welfare of others. This means that the separation between the owner (principal) and manager (agent) will create a conflict of interest. The conflict of interest that occurs will result in agency costs (monitoring costs, bonding costs and residual costs) which are useful for minimizing conflict of interest. With this agency cost, it will ultimately reduce the company's financial performance. Phenomenon in the field, the financial performance of mining sector companies listed on the IDX for the 2017-2019 period has an average of 5.25\% while the industry standard for financial performance (ROA) is $30 \%$ (Kasmir, 2016). The low financial performance is due to agency costs that arise because agency problems can be minimized by the presence of female directors. Because according to Steare and Stamboulides (2008) women have higher morale than men's morale which is measured by the values of honesty, politeness, attention and a person's reasons for doing work. The same thing was also stated by Peterson et al. (1991) who examined female directors. The results of research by Peterson et al. (1991) show that women are more concerned with ethical issues and value ethical issues more highly than men. And so are the results of research conducted by Eynon et al. (1997) who showed that women have a higher moral reasoning value than men. Sweeney et al (2010) supports research conducted by Peterson et al (1991) and Eynon et al (1997) which found that women have higher ethical judgments than men. The UK government has also published a Hampton Alexander report recommending the FTSE100 company to have 33\% women on the FTSE100 leadership team by 2020 .

The results of research conducted by the International Finance Corporation (2019), companies that have more than $30 \%$ of female board members report an average ROA of $3.8 \%$, while companies that do not have female board members have an ROA of 2.4\%. Isidro and Sobral (2015) have also examined women directors and company financial performance. The results of research conducted by Isidro and Sobral (2015) concluded that the presence of women on the board of directors has a positive relationship with the company's financial performance. Similar research has also been carried out by Lückerath-Rovers (2013) and found that the presence of women on the board of directors has better performance compared to the performance of companies without women on the board of directors. Meanwhile, research conducted by Singhathep and Pholphirul (2015) on manufacturing sector companies in Thailand stated that female CEOs of manufacturing companies in Thailand had a negative effect on the company's financial performance. Similar research results have also been produced by Mohammad, Abdullatif, \& Zakzouk (2018) which found that there was no significant relationship between the percentage of women on the board of directors, top and medium level executive management with financial performance. Likewise, research conducted by Astuti (2017) in Indonesia shows that the presence of women on the board of directors has no effect on the company's financial performance. The inconsistent results of this study encourage the authors to re-examine the effect of female directors on the company's financial performance. 
Based on the research background that has been described, the formulation of the problem in this study is: "Does the presence of a female board of directors affect the financial performance of mining sector companies listed on the IDX". Meanwhile, the objective to be achieved in this study is to see and analyze the influence of the presence of female directors on the financial performance of mining sector companies listed on the Indonesia Stock Exchange.

The results of this study are expected to be of benefit to: (1) the company, in terms of making decisions when selecting directors by considering the presence of women; (2) Investors, when investing, pay more attention to companies that have female directors; (3) Regulators, when making regulations, must consider the minimum number of women on the board of directors.

\section{Literature Review}

\subsection{Financial Performance}

Financial performance is the result of management's ability to manage company resources (Makhdalena, 2014). According to Berle \& Means (1932) the company is a system, namely a collection of stakeholders (investors, management, creditors, suppliers, society, government, etc.). The purpose of establishing a company is to increase the prosperity of stakeholders. In order for the company to survive, the company must have an ever-increasing performance. According to Adam Smith (1776), to improve financial performance, specialization must be done, namely the separation between the principal and the agent. Agents are self-interested human beings (Jensen and Meckling, 1976) who always want to improve their welfare even though they have to sacrifice the welfare of others, which is also known as conflict of interest. It can create agency costs (monitoring costs, bonding costs and residual costs) in order to minimize conflicts of interest. This agency cost will ultimately reduce the company's financial performance. According to Lückerath-Rovers (2013); Brahma et al (2020); Qian (2016); Salloum et al. (2016); Post \& Byron (2015); Emestine \& Setyaningrum (2019); Mohammad et al. (2018); Bianchi \& Iatridis (2014), financial performance can be improved by the presence of female directors.

Research on company financial performance has been carried out by many previous researchers, such as research by Pratheepkanth (2011) on companies listed on the Colombo Stock Exchange for corporate financial performance indicators using gross profit, net profit, ROCE, ROE and ROA. Fauzi and Locke's (2012) research on companies listed on the New Zealand Stock Exchange used ROA and Tobin's Q to measure the company's financial performance. Furthermore, Surifah (2013) has research on family control, board of directors and bank performance. Bank performance indicators use ROA, ROE and Non Performing Loans (NPL). Pervan and Višić's (2012) study measures business success using ROA and ROE indicators as well as firm size and leverage. In this study, the company's financial performance indicators use Return on Assets (ROA) (Pratheepkanth, 2011; Fauzi and Locke, 2012; Pervan and Visic, 2012; Surifah, 2013). This is done because ROA describes the efficient use of company assets in operations to generate profits.

The company's financial performance is influenced by many factors, such as the results of research conducted by Agrawal and Knoeber (1996) which concluded that blockholders ownership, firm size, leverage, management ownership, institutional ownership, managerial labor, independent commissioners and audit committees affect the company's financial performance. . The results of research conducted by Agrawal and Knoeber (1996) are supported by research conducted by Makhdalena (2014) which concluded that blockholders ownership, firm size and leverage have an effect on the company's financial performance. Isidro and Sobral (2015) have also examined the financial performance of women directors. The results of his research concluded that the presence of women on the board of directors has a positive relationship with the company's financial performance. The same results have also been carried out by Lückerath-Rovers (2013); Brahma et al (2020); Qian (2016); Salloum et al. (2016); Post \& Byron (2015). Emestine \& Setyaningrum (2019); Mohammad et al. (2018); Bianchi \& Iatridis (2014).

\subsection{Women Directors}

Female directors are women who are on the board of directors. Research on female directors has been carried out by many previous researchers, such as: Steare and Stamboulides (2008) measured the moral DNA of a person from their system of entering the workplace and he found that women have higher morale than men's morale which is measured by the value of honesty, politeness, concern and reason for someone doing work. Peterson et al. (1991) have also examined female directors, the results show that women are more concerned with ethical issues and value ethical issues higher than men. And so are the results of research conducted by Eynon et al. (1997) who showed that women have a higher moral reasoning value than men. Sweeney et al. (2010) support research conducted by Peterson et al. (1991) and Eynon et al. (1997) who found that women have higher ethical judgments than men.

The results of a study conducted by Lückerath (2013) examined the financial performance of Dutch companies with and without women on the board of directors of 99 companies listed on the Dutch Women's Council Index. The results show that companies with female directors perform better than firms without women on their boards of directors. In contrast to the results of research conducted by Singhathep and Pholphirul (2015) 
in manufacturing companies in Thailand, it is stated that female CEOs of manufacturing companies in Thailand have a negative effect on the company's financial performance. Meanwhile, the results of research conducted by Qian (2016) concluded that company performance was positively related to female directors. Likewise, the results of research conducted by Post and Byron (2014) concluded that women on the board of directors have a positive relationship with the company's financial performance. The same thing was also produced by Brahma et al (2020) who conducted research in England. The results of his research concluded that there is a positive and significant relationship between gender diversity and the company's financial performance. The results of this study were more significant when 3 or more women became directors compared to 2 or less women. While the results of research conducted by Mohammad et al. (2018) found that there was no significant relationship between the percentage of women on the board of directors, top and medium level executive management with financial performance. Salloum et al. (2016) conducted a study on Lebanon's top 30 companies to see the influence of the presence of women in management on company performance. The results showed that the presence of women in management in Lebanon was not positively correlated with the company's financial performance. Women in high managerial positions are most likely members of the family who own the business, and therefore they do not care directly about business management. Additionally, a large number of women surveyed in the sample were married. As a result, their priorities changed, and they put their families before their career development.

Emestine \& Setyaningrum (2019) examined the relationship between the characteristics of the Chief Executive Officer (CEO) and company performance. By using Tobin's Q to measure company performance; while $\mathrm{CEO}$ characteristics are measured by tenure, age, professional certification in finance or accounting, further education in finance or accounting, status (insider or outsider) and gender. The hypothesis which is tested using regression analysis is using 235 firm-year observations from six ASEAN countries (Singapore, Malaysia, Indonesia, Thailand, Philippines, and Vietnam) in 2015. The results show that the CEO's age and tenure have a positive relationship with the company performance. This study is important because it provides evidence about the relationship between CEO characteristics and firm performance. CEO characteristics will have a positive impact on company performance. Overall, investors need to pay attention to the essence of a CEO which is proven to be able to influence better company performance in making investment decisions.

Bianchi \& Iatridis (2014) examined the impact of board gender diversity on corporate financial performance. The focus is on CAC 40 constituents and the investigative period from 2008 to 2012. The study found that companies with a higher proportion of women on their boards outperformed firms with a lower proportion in terms of return on sales and EBITDA margins. The questionnaire survey shows that increasing board gender diversity leads to better corporate governance and increased firm value.

\subsection{Female Directors and Company Financial Performance}

Female directors are the presence of women on the board of directors as measured by the percentage of the number of women on the board of directors. The company's financial performance is the result of management's ability to manage the company's resources. According to the results of the study, female directors affect the company's financial performance, as research has been conducted by Lückerath-Rovers (2013). Lückerath-Rovers (2013) found that the presence of women on the board of directors has better performance compared to the performance of companies without women on the board of directors. Likewise, research conducted by Qian (2016) concluded that company performance is positively related to female directors. Furthermore, the results of research conducted by Post and Byron (2014) concluded that women on the board of directors have a positive relationship with the company's financial performance. The same thing was also produced by Brahma et al (2020) who conducted research in England. The results of his research concluded that there is a positive and significant relationship between gender diversity and the company's financial performance. The results of this study were more significant when 3 or more women became directors compared to 2 or less women.

Emestine \& Setyaningrum (2019) examined the relationship between the characteristics of the Chief Executive Officer (CEO) and company performance. By using Tobin's Q to measure company performance; while CEO characteristics are measured by tenure, age, professional certification in finance or accounting, further education in finance or accounting, status (insider or outsider) and gender. The hypothesis is tested using regression analysis using 235 firm-year observations from six ASEAN countries (Singapore, Malaysia, Indonesia, Thailand, Philippines, and Vietnam) in 2015. The results show that the CEO's age and tenure have a positive relationship with the company performance. This study is important because it provides evidence about the relationship between CEO characteristics and firm performance. CEO characteristics will have a positive impact on company performance. Overall, investors need to pay attention to the essence of a CEO which is proven to be able to influence better company performance in making investment decisions.

Bianchi \& Iatridis (2014) examined the impact of board gender diversity on corporate financial performance. The focus is on CAC 40 constituents and the investigative period from 2008 to 2012. The study found that companies with a higher proportion of women on their boards outperformed firms with a lower proportion in terms of return on sales and EBITDA margins. The questionnaire survey shows that increasing board gender diversity 
leads to better corporate governance and increased firm value.

Female directors affect the company's financial performance because according to Steare and Stamboulides (2008) women have higher morale than men's morale which is measured by the values of honesty, politeness, concern and a person's reasons for doing work. Peterson et al. (1991) have also examined female directors, the results show that women are more concerned with ethical issues and value ethical issues higher than men. And so are the results of research conducted by Eynon et al. (1997) who showed that women have a higher moral reasoning value than men. Sweeney et al (2010) supports research conducted by Peterson et al. (1991) and Eynon et al. (1997) who found that women have higher ethical judgments than men. So with the high morale of women, the conflict of interest that occurs in the company can be mitigated by the presence of female directors.

Based on the research background and literature review, the hypothesis of this study is: Female directors have an effect on the company's financial performance.

\section{Research Methods}

The type of this research is descriptive quantitative research. The object of this research is female directors with an indicator of the proportion of female directors on the board of directors and financial performance with an indicator of ROA. While the control variables in this study are firm size, leverage and age. The population of this study is the mining sector companies listed on the IDX which have complete data for the 2017-2019 period, totaling 16 companies with 48 years of observation and all of them researched (census). The type of data from this study is secondary data from the annual report for data on female directors obtained through idx.co.id. Meanwhile, the ROA, size, leverage and age data were obtained from Thomson \& Reuters. The data analysis technique in this study used path analysis with SPSS.

Table 1. Research Variable Operationalization

\begin{tabular}{|l|l|l|l|}
\hline Variable & Concept & Indicator & Scale \\
\hline Women Directors $\left(\mathrm{X}_{1}\right)$ & Women who become company directors & $\begin{array}{l}\text { Proportion of female } \\
\text { directors } \\
\text { Natural logaritma from } \\
\text { total assets } \\
\text { the ratio of debt to assets }\end{array}$ & Ratio \\
Leverage $\left(\mathrm{X}_{3}\right)$ & Firm size is the size of the company \\
Age $\left(\mathrm{X}_{4}\right)$ & $\begin{array}{l}\text { Leverage, which is the number of assets } \\
\text { financed with debt } \\
\text { Company age since listed (Liu \& } \\
\text { Anbumozhi, 2009) } \\
\text { The company's financial performance is the } \\
\text { result of management's ability to manage } \\
\text { the company's resources }\end{array}$ & Return on Assets (ROA) & Ratio \\
Performance $(\mathrm{Y})$
\end{tabular}

\section{Result and Discussion}

\subsection{Results of Descriptive Test of Corporate Financial Performance Variables}

The company's financial performance is the result of management's ability to manage the company's resources, which is calculated using Return on Assets (ROA). The data in Table 2 shows that the average financial performance of mining sector companies listed on the IDX is 0.0514 or $5.14 \%$. This average ROA is below the industry standard, which is $30 \%$.

Tabel 2. Descriptive Analysis Company Financial Performance (ROA)

\begin{tabular}{|l|l|l|}
\hline Financial Performance (Y) & Total & Percentage \\
\hline Standard Deviation & .27898 & - \\
Average & .0514 & - \\
Below average & 29 & 60.4 \\
Above average & 19 & 39.6 \\
Maximum & .61 & - \\
Minimum & -1.54 & - \\
\hline
\end{tabular}

Source: Secondary data processing (2021)

\subsection{Results of Descriptive Analysis of Women Directors Variable}

Women directors are women who occupy the board of directors of a company with an indicator, namely the number of women who occupy the board of directors compared to the total number of directors. The data in Table 3 shows that the average women board of directors in mining sector companies listed on the IDX is 0.1447 or $14.47 \%$. On average, women directors of mining sector companies listed on the IDX have women directors below the standard set by Alexander, which is $33 \%$. 
Table 3. Descriptive Analysis Women Directors

\begin{tabular}{|l|l|c|}
\hline Women Directors $(\mathrm{X} 1)$ & Total & Percentage \\
\hline Standard Deviation & .0584 & - \\
Average & .1447 & - \\
Below average & 27 & $56.25 \%$ \\
Above average & 21 & $43.75 \%$ \\
Maximum & .29 & - \\
Minimum & .07 & - \\
\hline
\end{tabular}

Source: Secondary data processing (2021)

\subsection{Hypothesis Test Results}

In a diagram, the variable structure of Female directors, Age, Leverage and Size on the financial performance of mining sector companies listed on the IDX is shown in Table 4. Furthermore, the influence of women directors variables, age, leverage and size on the financial performance of mining sector companies listed on the IDX, both simultaneously and partially shown in Table 4.

Table 4. Path Analysis The Effect of Women Directors, Age, Leverage and

Size on Financial Performance

\begin{tabular}{|l|l|l|}
\hline Variable & Path Coefficient (Beta) & Impact \\
\hline Women directors $\left(\mathrm{X}_{1}\right)$ & 0.026 & 0.001 \\
Age $\left(\mathrm{X}_{2}\right)$ & -0.102 & 0.010 \\
Leverage $\left(\mathrm{X}_{3}\right)$ & -0.097 & 0.009 \\
Size $\left(\mathrm{X}_{4}\right)$ & 0.477 & 0.228 \\
\hline
\end{tabular}

Source: Secondary data processing (2021)

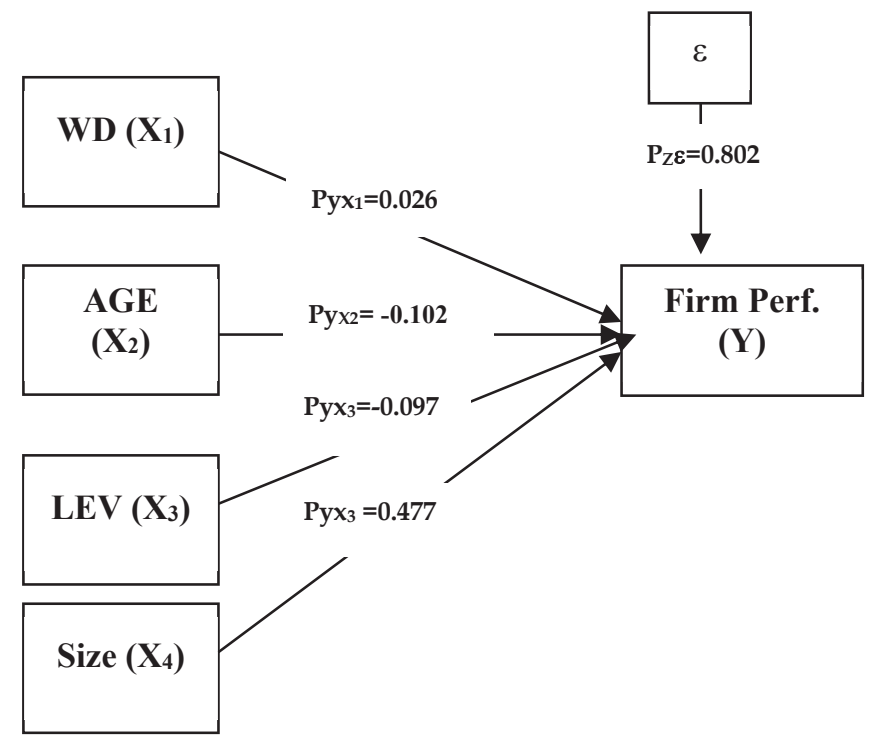

Figure 1. Path Diagram Influence of Women directors, Age, Leverage and Size on Firm Performance

The magnitude of the influence of women directors, age, leverage and size on the firm financial performance simultaneously can be seen from the coefficient of determination (R2), which is 0.198 or $19.8 \%$, while the remaining 0.802 (1- 0.198) is influenced by other factors outside the factors studied.

The simultaneous low influence of women directors' variables, age, leverage and size on the firm financial performance, which is $19.8 \%$, indicates that there are many other factors that affect the firm financial performance. Other factors include management ownership, institutional ownership, managerial labor, independent commissioners and audit committees (Agrawal and Knoeber, 1996) and blockholders (Makhdalena, 2014).

\subsection{Discussion}

From Table 4 it can be seen that the variables of women directors, age, leverage and size together are not strong enough to influence the firm financial performance. This can be seen from the data on the firm financial performance variables in Table 2, where the average financial performance is 0.0514 or $5.14 \%$. The majority of the firm financial performance is in a position below the average, which is $60.4 \%$ with a standard deviation of 0.2789 . This indicates that most of the mining sector firm financial performance listed on the IDX is still below the average (0.0514). 
The firm low financial performance is due to the low proportion of women directors, with an average value of only 0.1447 or $14.47 \%$. Hampton Alexander recommends the FTSE100 company to have 33\% women on the FTSE100 leadership team. The results of this study contradict research conducted by Lückerath-Rovers (2013); Brahma et al (2020); Qian (2016); Salloum et al (2016); Post \& Byron (2015). Emestine \& Setyaningrum (2019); Bianchi \& Iatridis (2014) and in line with research conducted by Singhathep and Pholphirul (2015); Mohammad et al (2018); and Astuti (2017) which states that women directors have no effect on the firm financial performance.

There is no influence of women directors on the performance of mining sector companies listed on the IDX because the number of women directors in mining companies listed on the IDX is very small, namely the average company has women directors of 0.1447 or $14.47 \%$ and those below the average are $56.25 \%$ and the remaining 43.75 above average. Of the total population of mining sector companies listed on the IDX, there are only 16 companies that have women directors for the 2017-2019 period. According to Suresh (2019), women directors do not affect the performance of companies listed on the IDX because the percentage of women on the board of directors of companies in the ASEAN region is still low because of the broad gender bias that considers women inappropriate for top executive positions. According to Salloum et al. (2016), women who occupy high managerial positions are likely to be family members who own the business and therefore they are not directly concerned with business management. Additionally, a large number of women surveyed in the sample were married. As a result, their priorities changed, and they put their families before their career development.

\section{Conclusion, Limitations and Suggestions \\ 5.1 Conclusion}

Based on the formulation of problems and research hypotheses and analysis of research results, it can be concluded that: female directors have no effect on the financial performance of mining sector companies listed on the IDX.

\subsection{Limitations}

This study used a population with a small number. This study also used the female director indicator, only the percentage of women on the board of directors.

\subsection{Suggestions}

Based on the conclusions of the research results, to improve the company's financial performance, it is suggested to: (1) for the next researchers it is recommended to increase the population with other sectors and to add a variable indicator for female directors with: age, education, years of service, marital status, relationship with the company; (2) for academics, it is hoped that the research results can provide valuable input in learning corporate governance by paying attention to the mechanism through female directors. While operational advice is expected (1) for regulators, it is suggested that they be able to make policies that can improve the company's financial performance by stipulating a minimum number of female directors in companies listed on the IDX; (2) for the company, it is expected that in making policies to pay attention to the portion of women on the board of directors; (3) for investors, in order to be able to take advantage of the votes they have in the election of the board of directors, it involves women with the portion that can decide the policy if voting is done.

\section{References}

Agrawal, A., \& Knoeber, C. R. (1996). Firm performance and mechanisms to control agency problems between managers and shareholders. Journal of financial and quantitative analysis, 377-397.

Astuti, E. P. (2017). Pengaruh diversitas dewan direksi terhadap nilai perusahaan pada perusahaan manufaktur yang terdaftar di Bursa Efek Indonesia Periode 2008-2011. KREATIF: Jurnal Ilmiah Prodi Manajemen Universitas Pamulang, 4(2).

Bianchi, M., \& Iatridis, G. (2014). Board gender diversity and corporate financial performance: evidence from CAC 40

Brahma, S., Nwafor, C., \& Boateng, A. (2020). Board gender diversity and firm performance: The UK evidence. International Journal of Finance \& Economics.

Emestine, I., \& Setyaningrum, D. (2019, October). CEO Characteristics and Firm Performance; Empirical Studies from ASEAN Countries. In 2018 International Conference on Islamic Economics and Business (ICONIES 2018). Atlantis Press.

Eynon, G., Hills, N. T., \& Stevens, K. T. (1997). Factors that influence the moral reasoning abilities of accountants: Implications for universities and the profession. Journal of Business ethics, 16(12), 1297-1309.

Fauzi, F., \& Locke, S. (2012). Board structure, ownership structure and firm performance: A study of New Zealand listed-firms.

Isidro, H., \& Sobral, M. (2015). The effects of women on corporate boards on firm value, financial performance, and ethical and social compliance. Journal of Business Ethics, 132(1), 1-19.

Jensen, M. C., \& Meckling, W. H. (1976). Theory of the firm: Managerial behavior, agency costs and ownership 
structure. Journal of financial economics, 3(4), 305-360.

Kasmir. (2016). Analisis Laporan Keuangan. Jakarta: Raja Grafindo Persada

Lückerath-Rovers, M. (2013). Women on boards and firm performance. Journal of Management \& Governance, 17(2), 491-509.

Makhdalena, M. (2014). Pengaruh Blockholders Ownership, Firm Size dan Leverage Terhadap Kinerja Keuangan Perusahaan. EKUITAS (Jurnal Ekonomi dan Keuangan), 18(3), 277-292.

Means, G. C. (1932). The separation of ownership and control in American industry. The Quarterly Journal of Economics, 46(1), 68-100.

Mohammad, S. J., Abdullatif, M., \& Zakzouk, F. (2018). The effect of gender diversity on the financial performance of Jordanian banks. Academy of Accounting and Financial Studies Journal, 22(2), 1-11.

Peterson, R. A., Beltramini, R. F., \& Kozmetsky, G. (1991). Concerns of college students regarding business ethics: A replication. Journal of Business Ethics, 10(10), 733-738.

Perinpanathan, R. (2014). Impact of financial leverage on financial performance special reference to John Keels Holdings PLC Sri Lanka. Scientific Research Journal (SCIRJ), 2.

Pervan, M., \& Višić, J. (2012). Influence of firm size on its business success. Croatian Operational Research Review, 3(1), 213-223.

Pratheepkanth, P. (2011). Capital structure and financial performance: evidence from selected business companies in Colombo stock exchange Sri Lanka. Researchers World, 2(2), 171.

Qian, M. (2016). Women's leadership and corporate performance. Asian Development Bank Economics Working Paper Series, (472).

Salloum, C., Azzi, G., Mercier-Suissa, C., \& Khalil, S. (2016). The rise of women and their impact on firms' performance. International Journal of Entrepreneurship and Small Business, 27(2-3), 213-246.

Singhathep, T., \& Pholphirul, P. (2015). Female CEOs, firm performance, and firm development: evidence from Thai manufacturers. Gender, Technology and Development, 19(3), 320-345.

Smith, A. (1776). An inquiry into the nature and causes of the wealth of nations: Volume One. London: printed for W. Strahan; and T. Cadell, 1776.

Steare, R., \& Stamboulides, P. (2008). Who's doing the right thing. London: Roger Steare Consulting Limited.

Surifah. (2013). Family Control, Board of Directors and Bank Performance in Indonesia. American International Journal of Contemporary Research, 3(6), 115-124.

Sweeney, B., Arnold, D., \& Pierce, B. (2010). The impact of perceived ethical culture of the firm and demographic variables on auditors' ethical evaluation and intention to act decisions. Journal of Business Ethics, 93(4), 531551. 